\title{
The Physico-Chemical Quality of Effluents of Selected Sewage Treatment Plants Draining into River Rwizi, Mbarara Municipality, Uganda
}

\author{
Jeninah Atwebembeire ${ }^{1 *}$, Morgan Andama², Jane Yatuha1', Julius Bunny Lejju1, \\ Grace Kagoro Rugunda ${ }^{1}$, Joel Bazira ${ }^{3}$ \\ ${ }^{1}$ Department of Biology, Faculty of Science, Mbarara University of Science and Technology, Mbarara, Uganda \\ ${ }^{2}$ Department of Biology, Faculty of Science, Muni University, Arua, Uganda \\ ${ }^{3}$ Department of Microbiology, Faculty of Medicine, Mbarara University of Science and Technology, Mbarara, Uganda \\ Email: *atwebembeirej@must.ac.ug
}

How to cite this paper: Atwebembeire, J., Andama, M., Yatuha, J., Lejju, J.B., Rugunda, G.K. and Bazira, J. (2019) The Physico-Chemical Quality of Effluents of Selected Sewage Treatment Plants Draining into River Rwizi, Mbarara Municipality, Uganda. Journal of Water Resource and Protection, 11, 20-36.

https://doi.org/10.4236/jwarp.2019.111002

Received: November 29, 2018

Accepted: January 11, 2019

Published: January 14, 2019

Copyright $\odot 2019$ by author(s) and Scientific Research Publishing Inc. This work is licensed under the Creative Commons Attribution International License (CC BY 4.0).

http://creativecommons.org/licenses/by/4.0/

\begin{abstract}
As population increases in urban areas, the domestic and industrial activities increase resulting in an increase in the volumes of wastewater and anthropogenic pollution, hence posing a threat to public health and environment. This study assessed the physical chemical quality of two main sewage plant effluents discharging into River Rwizi. Effluent water samples were analyzed for dissolved oxygen, colour, turbidity, total suspended solid, total iron, phosphates, alkalinity, magnesium, calcium carbonate, temperature, $\mathrm{pH}$, ammonium, electrical conductivity, chloride and nitrates. Parameters were analyzed following standard methods of APHA (1985). The values obtained were compared with EPA (2001), NWSC (2015) and NEMA (1999) standards for waste water. Results showed that the mean values most of the parameters tested were higher than the recommended EPA, NWSC and NEMA standards. The mean colour was $1627.67^{\circ} \mathrm{C}$ and $1414.33^{\circ} \mathrm{C}$ in Kakoba and Taso sewage effluents respectively compared to EPA (20-150), NWSC (500) and NEMA (300) standards ( $\mathrm{p}>0.05)$. The mean alkalinity was $1390.17 \mathrm{mg} / \mathrm{l}$ and $1308.33 \mathrm{mg} / \mathrm{l}$ for Kakoba and Taso respectively compared with EPA (400) and NWSC (800) standards. DO had a mean concentration of $68.27 \mathrm{mg} / \mathrm{l}$ and $63.03 \mathrm{mg} / \mathrm{l}$ in Taso and Kakoba respectively compared to EPA and NEMA standard of $5 \mathrm{mg} / \mathrm{l}$. Mg was $243.29 \mathrm{mg} / \mathrm{l}$ and $246.49 \mathrm{mg} / \mathrm{l}$ in Kakoba and Taso sewage effluents respectively compared to NEMA standard for waste water of $100 \mathrm{mg} / \mathrm{l}(\mathrm{p}>0.05)$. The mean $\mathrm{pH}$ was 8.26 and 8.16 in Taso and Kakoba sewage effluents respectively compared to NWSC and NEMA standard of 6.0 8.0. Phosphate mean concentration levels were $32.2 \mathrm{mg} / \mathrm{l}$ and $27.11 \mathrm{mg} / \mathrm{l}$ for Taso and Kakoba respectively compared to standards of EPA $(0.5-0.7 \mathrm{mg} / \mathrm{l})$ and NEMA $(10 \mathrm{mg} / \mathrm{l}) . \mathrm{NO}_{3}$ was $10 \mathrm{mg} / \mathrm{l}$ and $5.83 \mathrm{mg} / \mathrm{l}$ in Kakoba and Taso
\end{abstract}


sewage effluents respectively compared to NWSC maximum permissible limit of $5 \mathrm{mg} / \mathrm{l}$. The mean $\mathrm{NH}_{4}$ concentration was $385.33 \mathrm{mg} / \mathrm{l}$ (Kakoba) and 50.0 $\mathrm{mg} / \mathrm{l}$ (Taso) compared to the EPA guideline range $(0.2-4 \mathrm{mg} / \mathrm{l})$. Chloride (Cl) had a mean of $833.33 \mathrm{mg} / \mathrm{l}$ in Kakoba compared to EPA (250 mg/l), NWSC and NEMA (500 mg/l) standards. Therefore the study recommends for effective treatment of waste effluents from Kakoba and Taso sewage treatment plants before recycling in order to avoid pollution of river Rwizi.

\section{Keywords}

Physico-Chemical, Effluents, Sewage, River Rwizi, Mbarara Municipality

\section{Introduction}

Assessment of water and wastewater is very crucial to safeguard the public health and environment. The population of Mbarara Municipality has been rising rapidly from 69,400 in 2002 to 195,013 by August 2014 [1] [2]. As population increases, the domestic and industrial activities leading to increased volumes of wastewater and anthropogenic pollution also increases. Mbarara Municipality draws its piped water from River Rwizi, into which the sewage effluents are directed. As a result, the water in the River Rwizi has a dirty-brown colour with unpleasant smell. Due to the increased population and activities, more effluent discharge find their way directly or indirectly to the main river Rwizi, where poor people draw water from its banks for domestic purposes and this could cause water borne diseases to the surrounding community [1].

River Rwizi is the main source of water for home use and industries in Mbarara which is the largest town in western Uganda [3]. As the population in Mbarara Municipality increases, the demand for water also increases and more water is extracted. Water is a natural resource which forms an essential component of life. Over 1 billion people do not get access to safe drinking water worldwide and it is worse in developing countries including Uganda [4]. Rivers are vital and vulnerable freshwater systems to sustain all the life. However, the declining quality of water in freshwater system threatens their sustainability and therefore a cause for concern [5]. Fortunately, water challenges such as water scarcity, augmenting water supply, inequity, unaccounted water loss, ground water loss, and wastewater safe disposal, can be solved by implementing a zero discharge approach by treating and reusing the treated water [6]

For the case of Mbarara Municipality, attempts have been made to treat the generated wastewater in sewage treatment plants like Taso and Kakoba though there is less information on the efficiency of the treatment plants. If the wastewater is treated safely, and recycled, it will increase on the river water which is threatened to dry due to much demand from the increased population in the municipality. The study therefore, aims at assessing the physical chemical quality of the main two sewage plant effluents before it is discharged into River Rwizi. 


\section{Materials and Methods}

\subsection{Location of Study Area}

The study area was conducted in Mbarara Municipality $\left(00^{\circ} 36^{\prime} \mathrm{S} 30^{\circ} 36^{\prime} \mathrm{E}\right)$, a fast-growing town and the largest in Western Uganda [1]. Traversing Mbarara Municipality is river Rwizi which originates from the hills of Buhweju transecting through districts of Mbarara, Sheema, Ntungamo, Isingiro, Kiruhura, and Bushenyi before it pours its waters into Lake Victoria via the network of Lake Mburo, Lake Kachera, Lake Nakivale and Kijanebalola among others. River Rwi$\mathrm{zi}$ is the main Source of domestic water supply and drainage system for Mbarara Municipality [7]. Sewage effluent samples were obtained from the two divisions of Mbarara Municipality that is Kakoba and Kamukuzi which have sewage plants i.e. Kakoba and Taso respectively that drain their effluents directly into River Rwizi. The GPS coordinates of the sampling points were $0.6061^{\circ} \mathrm{S}$, $30.6741^{\circ} \mathrm{E}$ (Kakoba) and $0.6176^{\circ} \mathrm{S}, 30.6592^{\circ} \mathrm{E}$ (Taso) as shown in Figure 1.

\subsection{Effluent Water Sample Collection}

Effluent water samples were collected from the treated final effluent, at the discharge point using 1-litre plastic containers. At every sampling site, the plastic containers were cleaned with detergent solution, and rinsed several times with dilute nitric acid solution to avoid contamination with metals and then finally rinsed with distilled water, before sampling. Water samples were collected in clean plastic bottles. Sample bottles were completely filled and tightly secured. Water samples were analyzed within 5 hours from the time of collection and those not analyzed immediately were stored at $4{ }^{\circ} \mathrm{C}$ and warmed to room temperature before tests were carried out [8]. The sampling was done once a week

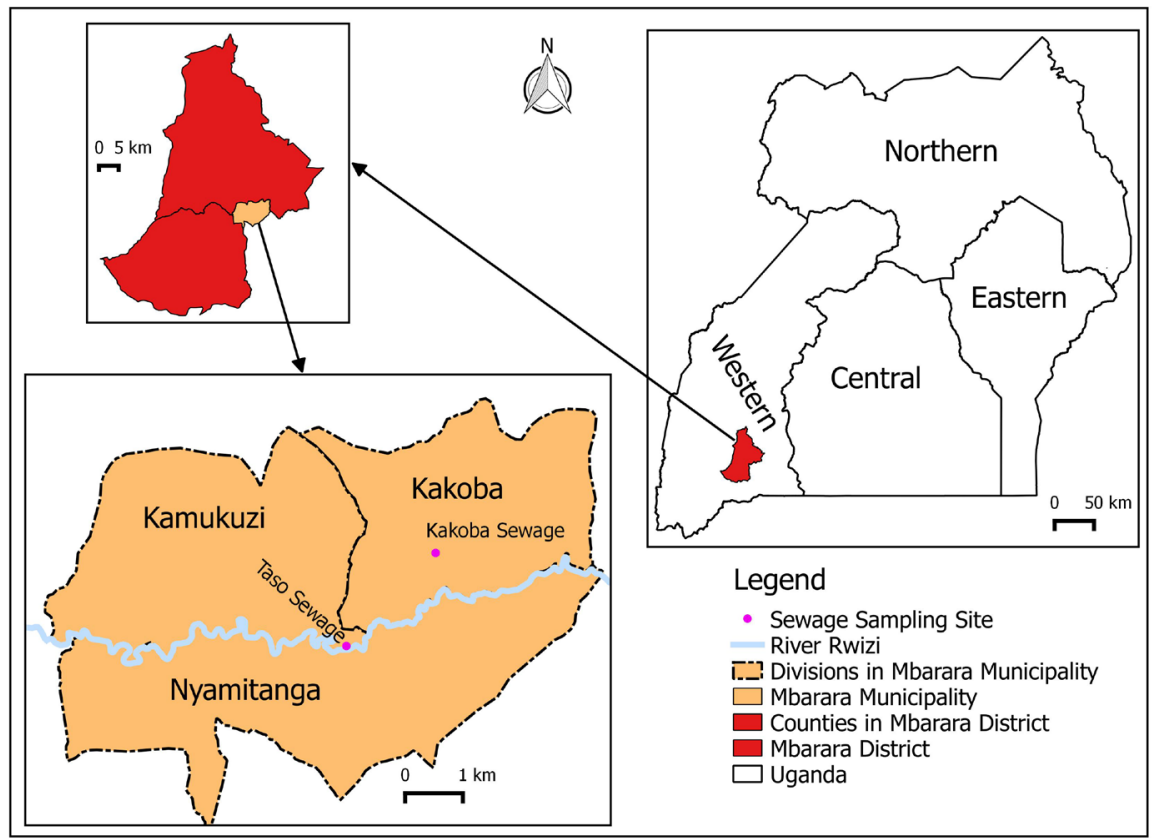

Figure 1. Map of Uganda showing the study location. 
for a period of six months, whereby three months (March, April and May) were in wet season and three months (June, July and August) were in dry season. A total of 48 effluent samples were purposively collected from the two (2) streams in 2017. From each site of the stream, effluent samples were collected in triplicates per sampling visit. Samples were collected from 8.00 am to 12 noon periods of the day for the dry and wet seasons.

\subsection{Physico-Chemical Analysis}

Wastewater samples were collected for physico-chemical analysis following standard methods [9]. Physiochemical analyses of sewage effluents were performed using standard methods for American Public Health Association and standard operating manual [2]. The full procedures of analysis of each of the physico-chemical parameters (dissolved oxygen, colour, turbidity, total suspended solid, total iron, phosphates, alkalinity, magnesium, calcium carbonate, temperature, $\mathrm{pH}$, ammonium, electrical conductivity, chloride and nitrates) are detailed in the study by [10].

\subsection{Data Analysis}

Data from the two sites and sampling periods were entered in MS Excel ver. 2013 and enumerated for descriptive statistics (range, mean, coefficient of variation (CV)) with the results presented in tables and graphs. Variations in physicochemical parameters between Kakoba and Taso sewage plants as well as between March to May and June to August sampling periods were compared using student $t$ test in SPSS Ver. 20 at $5 \%$ level of significance.

\section{Results and Discussion}

\subsection{Physico-Chemical Parameters in Sewage Effluents Draining into River Rwizi}

\subsubsection{Temperature $\left({ }^{\circ} \mathrm{C}\right)$}

Temperature is a key factor in biological activity and microorganisms can be psychrophilic, mesophilic and thermophilic [11]. Aquatic organisms thrive only within specific temperature ranges [10]. Temperature exhibited very low variability within samples in Taso and Kakoba sewage effluents (CV; 15.14 and $18.36 \%$ respectively) with statistically insignificant variation of mean temperature in Taso sewage $\left(29.02^{\circ} \mathrm{C}\right)$ and Kakoba sewage $\left(25.05^{\circ} \mathrm{C}\right)$ as shown in Table 1. The mean temperature values in the sewage effluents were within the NEMA [12] maximum permissible limit $\left(20^{\circ} \mathrm{C}-35^{\circ} \mathrm{C}\right)$ but slightly higher than EPA [13] standard $\left(25^{\circ} \mathrm{C}\right)$ for water. Temperature does not vary significantly during the March-May and June-August sampling periods in the Kakoba $(\mathrm{t}=1.379, \mathrm{p}=$ $0.240)$ and Taso $(t=2.284, p=0.084)$ sewage effluents as shown in Figure 2. Lack of significant variation of temperature between the two sampling sites (Kakoba, Taso) is probably due to location of the sewage plants within similar geographical area (Mbarara municipality) with relatively uniform weather 
Table 1. Physico-chemical parameters of sewage effluents along R. Rwizi in Mbarara Municipality.

\begin{tabular}{|c|c|c|c|c|c|c|c|c|c|c|c|}
\hline \multirow{2}{*}{$\begin{array}{l}\text { Site }(\mathrm{N}=6) \\
\text { Parameters }\end{array}$} & \multicolumn{3}{|c|}{ Kakoba sewage } & \multicolumn{3}{|c|}{ Taso sewage } & \multicolumn{2}{|c|}{ Student $\mathrm{t}$ test } & \multicolumn{3}{|c|}{ Standards } \\
\hline & Range & Mean & CV (\%) & Range & Mean & CV (\%) & $\mathrm{T}$ & $\mathrm{P}$ & [13] & [16] & [12] \\
\hline Temperature $\left({ }^{\circ} \mathrm{C}\right)$ & $21.10-34.1$ & 25.05 & 18.36 & $21.30-34.0$ & 29.02 & 15.14 & 1.528 & 0.158 & 25 & - & $20-35$ \\
\hline Colour (TCUs) & $1319-1882$ & 1627.67 & 14.67 & $995-1746$ & 1414.33 & 20.62 & 1.386 & 0.196 & $20-150$ & 500 & 300 \\
\hline TSS (mg/l) & $167-249$ & 214 & 13.08 & $118-351$ & 182.5 & 48.39 & 0.833 & 0.424 & 50 & 100 & 100 \\
\hline Turbidity (NTUs) & $104.5-256.0$ & 186.63 & 29.75 & $138-371.5$ & 261.83 & 33.62 & 1.77 & 0.107 & - & 300 & 300 \\
\hline $\mathrm{pH}$ & $7.77-8.46$ & 8.16 & 3.3 & $7.73-8.90$ & 8.26 & 5.3 & 0.485 & 0.638 & $5.5-9.0$ & $6.0-8.0$ & $6.0-8.0$ \\
\hline Alkalinity (mg/l) & $300-2911$ & 1390.17 & 85.6 & $310-2400$ & 1308.33 & 66.07 & 0.473 & 0.647 & 400 & 800 & - \\
\hline $\mathrm{EC}(\mu \mathrm{s} / \mathrm{cm})$ & $824-1195$ & 1021.17 & 17.01 & $489-1102$ & 816 & 31.56 & 1.618 & 0.137 & 1000 & 1500 & \\
\hline $\mathrm{DO}(\mathrm{mg} / \mathrm{l})$ & $50-82.70$ & 63.03 & 21.97 & $48.9-89.4$ & 68.27 & 20.56 & 0.65 & 0.53 & 5 & - & 5 \\
\hline $\begin{array}{c}\text { Hardness, } \mathrm{CaCO}_{3} \\
(\mathrm{mg} / \mathrm{l})\end{array}$ & $191-4500$ & 1591.00 & 109.26 & $827-1220$ & 981.33 & 15.77 & 0.856 & 0.412 & - & - & - \\
\hline $\mathrm{Mg}(\mathrm{mg} / \mathrm{l})$ & $41.2-608$ & 243.29 & 92.13 & $175.1-299.1$ & 246.49 & 21.5 & 0.034 & 0.974 & - & - & 100 \\
\hline $\mathrm{Fe}(\mathrm{mg} / \mathrm{l})$ & $0.81-1.46$ & 1.13 & 22.8 & $0.70-1.75$ & 1 & 38.02 & 0.691 & 0.505 & $0.2-2.0$ & - & 10 \\
\hline $\mathrm{PO}_{4}(\mathrm{mg} / \mathrm{l})$ & $18.32-35.10$ & 27.11 & 28.25 & $21.63-38.75$ & 32.2 & 18.66 & 1.279 & 0.23 & $0.5-0.7$ & - & 10 \\
\hline $\mathrm{NO}_{3}(\mathrm{mg} / \mathrm{l})$ & $0-25$ & 10 & 122.47 & $0-25$ & 5.83 & 174.96 & 0.64 & 0.536 & 50 & 5 & - \\
\hline $\mathrm{NH}_{4}(\mathrm{mg} / \mathrm{l})$ & $356-400$ & 385.33 & 5.9 & $0-60$ & 50 & 48.99 & 24.585 & $2.83 \mathrm{E}-10$ & $0.2-4$ & - & - \\
\hline $\mathrm{Cl}(\mathrm{mg} / \mathrm{l})$ & $0-1000$ & 833.33 & 48.99 & 0 & 0 & 0 & 5 & 0.001 & 250 & 500 & 500 \\
\hline
\end{tabular}

$\mathrm{CV}-$ Coefficient of variation.

conditions. However, the slight differences could be attributed to the variation in sampling time as was similar to [14].

\subsubsection{Colour}

Color in wastewater is mainly from municipal contamination and industrial impurities of iron and manganese and other corrosive products [15]. Organic matter present in water is usually associated with humus, minerals and other materials which are natural impurities and corrosive products. The within sample variability of colour for the sewage effluents in Kakoba and Taso was still very low (CV; $14.67 \%-20.62 \%)$. The mean colour of the two sewage effluents i.e. Kakoba $\left(1627.67^{\circ} \mathrm{C}\right)$ and Taso $\left(1414.33^{\circ} \mathrm{C}\right)$ did not vary significantly $(\mathrm{p}>$ 0.05). However, the colour (TCUs) of the sewage effluents were higher than the EPA (20 - 150), NWSC, 500 [16] and NEMA (300) standards. Colour did not also vary significantly during the March-May and June-August sampling periods in the Kakoba $(t=0.964, p=0.389)$ and Taso $(t=0.245, p=0.819)$ sewage effluents. The mean color of the two sites that is Kakoba and Taso did not vary significantly because they were both generated from the same municipal and treated in a similar way. Furthermore, colour did not vary significantly during dry and wet seasons because the effluents were not influenced by runoffs from the rains and soils since the wastewater was pipped direct to sewage plants. This was also similar to the study by [14] [17]. 


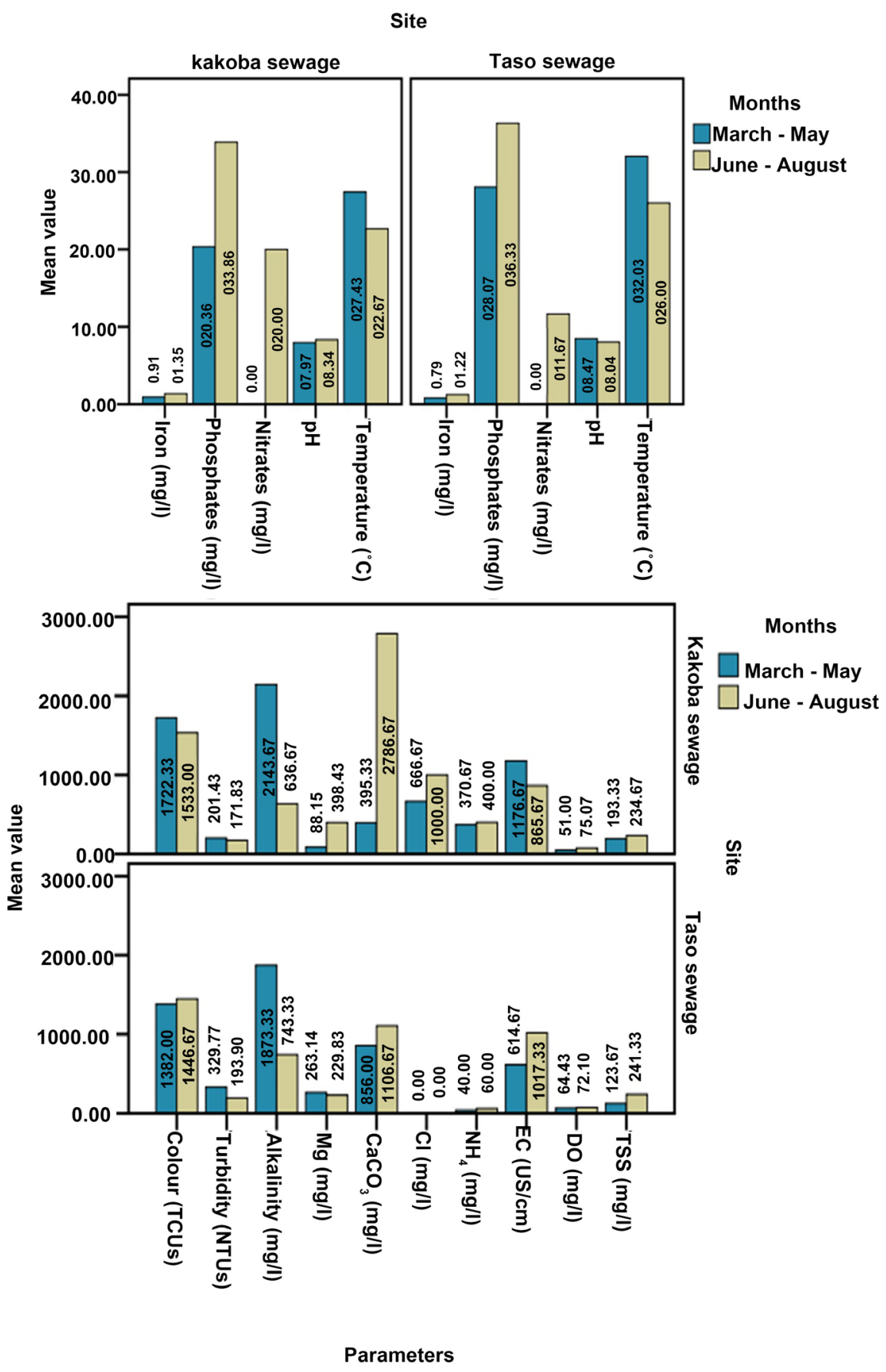

Figure 2. Physico-chemical parameters in Kakoba and Taso sewage effluents during March to May and June to August sampling periods.

\subsubsection{Total Suspended Solids (TSS)}

Total suspended solids apply to the dry weight of the material which is removed from a measured volume of water sample by filtration through a standard filter. The test is basically empirical and usually does not subject to the usual criteria of accuracy [18] [19]. As shown in Table 1, there was very low variability of total suspended solids (TSS) within sample in Kakoba sewage effluents (CV = 13.08\%). On the other hand, the variability of TSS within samples of Taso sewage efflu- 
ents was moderate $(\mathrm{CV}=48.39 \%)$. Kakoba $(214 \mathrm{mg} / \mathrm{l})$ and Taso $(182.5 \mathrm{mg} / \mathrm{l})$ sewage effluents recorded no significant $(\mathrm{p}>0.05)$ variation in the mean TSS though the values were both higher than EPA (50 mg/l), NWSC and NEMA (100 $\mathrm{mg} / \mathrm{l})$ standards. Similarly, there is no significant variation of TSS in Kakoba ( $\mathrm{t}=$ 2.752, $\mathrm{p}=0.051)$ and Taso $(\mathrm{t}=2.135, \mathrm{p}=0.100)$ sewage effluents during the March-May and June-August sampling periods. Taso recorded slightly higher total suspended solids compared to Kakoba because Taso sewage is located in the center of Municipality compared to the Kakoba which is a bit far from center of municipality. However both Taso and Kakoba sites had TSS values higher than the standards of EPA and NEMA attributed to the municipal wastes in agreement with [18] [20].

\subsubsection{Turbidity}

Turbidity is an important parameter because it refers to water clarity. Hence the more turbid the waste water appears, the higher the measured turbidity values [21]. Turbidity is an important determinant of the condition of the water and its productivity [22]. From Table 1, there was low variability of turbidity within samples in both Taso and Kakoba effluents (CV; 29.75\% - 33.62\%) with insignificant $(\mathrm{p}>0.05)$ difference recorded between sewage effluents in both Taso (261.83 NTUs) and Kakoba (186.63 NTUs). However, the mean turbidity of the effluents was lower than the NWSC and NEMA maximum permissible limits in waste water of 300 NTUs. Turbidity did not also vary significantly during the March-May and June-August sampling periods in Kakoba $(\mathrm{t}=0.611, \mathrm{p}=0.574)$. However, TSS was significantly higher during the March-May sampling period than the June-August period in sewage effluents in Taso $(t=3.165, p=0.034)$. March-May was significantly higher than June-August because there was much greater number of suspended solids carried by runoff during wet season than in dry season. Major sources of turbidity in the open water bodies is typically clay and silt from erosion, organic detritus, phytoplankton and water discharge [23].

\subsection{5. $\mathrm{pH}$}

$\mathrm{pH}$ is the concentration of hydrogen ions and is calculated by the negative logarithm of the hydrogen ion $(\mathrm{H}+)$ [24]. $\mathrm{pH}$ represents an important characteristic of water and small changes in its level can disorganize the quality of water making it unsuitable for use as it influences the availability of micronutrients as well as trace metals [25]. High $\mathrm{pH}$ values also alters the toxicity of other pollutants in the river, basing on an example of ammonia which is much more toxic in alkaline water than acid due to free ammonia $\mathrm{NH}_{3}$ [26]. $\mathrm{pH}$ is also an important parameter in evaluating the acid-base balance of water [27]. Thus $\mathrm{pH}$ of valve of 7 is neutral, a pH less than 7 is acidic, and a $\mathrm{pH}$ greater than 7 represents base saturation or alkaline. Both Kakoba and Taso sewage effluents exhibited very low within sample variability of $\mathrm{pH}(\mathrm{CV} ; 3.3 \%$ - 5.3\%). Similarly mean $\mathrm{pH}$ did not vary significantly between Taso $(\mathrm{pH}=8.26)$ and Kakoba $(\mathrm{pH}=8.16)$ sewage effluents. Nevertheless, the mean $\mathrm{pH}$ values in both the sewage effluents were 
slightly higher than the NWSC and NEMA maximum permissible limit of 6.0 8.0 but the values were within the EPA range (5.5 - 9.0). There was no significant variation of TSS in Kakoba $(t=2.340, p=0.079)$ and Taso $(t=1.277, p=0.271)$ sewage effluents during the March-May and June-August sampling periods.

\subsubsection{Alkalinity}

Alkalinity is the capability of water to neutralize acid. It is vital for fish and other aquatic life because it buffers against rapid $\mathrm{pH}$ changes [28] [29]. Living organisms, especially aquatic life, function best in a $\mathrm{pH}$ range of 6.0 to 9.0. Alkalinity is a measure of how much acid can be added to a liquid without causing a large change in $\mathrm{pH}$. The within sample variability of alkalinity was high in effluents of Taso and Kakoba sewage (CV; 66.07\% and 85.6\%). Both of the sewage effluents recorded insignificantly $(\mathrm{p}>0.05)$ different amounts of alkalinity i.e. Kakoba $(1390.17 \mathrm{mg} / \mathrm{l})$ and Taso $(1308.33 \mathrm{mg} / \mathrm{l})$. However, both Kakoba and Taso sewage effluents recorded much higher alkalinity values than EPA (400) and NWSC (800) standards. Similarly, alkalinity did not vary significantly during the March-May and June-August sampling periods in Kakoba $(t=1.926, p=0.126)$ and Taso $(t=2.051, \mathrm{p}=0.110)$ sewage effluents.

Alkalinity was higher in both sewage effluents than the standard guideline values. This may be attributed to the high amounts of anionic surfactants and alkalis associated with commonly used domestic detergents (e.g. omo etc.) which are carried by domestic effluents into the sewage treatment plants. [30] reported presence of anionic surfactants and alkalis in detergents like Omo.

\subsubsection{Electrical Conductivity (EC)}

Electric conductivity is very important parameter because it measures the dissolved solids in water bodies [31] [32]. Variations in EC [15] of any particular water body depend on the fluctuation in salinity and total dissolved solids. The within sample variability of electrical conductivity (EC) in Kakoba sewage effluents was very low $(\mathrm{CV}=17.01 \%)$ while that in Taso effluents was low $(\mathrm{CV}=$ $31.56 \%)$. The difference in mean EC in Kakoba $(1021.17 \mu \mathrm{s} / \mathrm{cm})$ and Taso $(816$ $\mu \mathrm{s} / \mathrm{cm}$ ) sewage effluents was not significant. Fortunately, the mean EC in both sewage effluents were below the NWSC maximum limit $(1500 \mu \mathrm{s} / \mathrm{cm})$. However, only the mean EC in Taso sewage effluent was below the EPA standard (1000 $\mu \mathrm{s} / \mathrm{cm}$ ) while that in Kakoba sewage was slightly higher than the EPA standard. Electrical conductivity was significantly higher during the March-May sampling period than June-August period in Kakoba sewage effluents $(t=10.015, p=$ 0.001) while EC was higher during the June-August sampling period than the March-May period in Taso sewage effluents $(t=3.319, p=0.029)$. Electric conductivity in both sewage effluents were generally low probably attributed to low levels of dissolved ions in the sewage effluents after treatment. Possibly the treatment plants were a bit effective in removing the dissolved ions in the sewage before discharge into river Rwizi. According to [33], the sewage treatment process is effective in removing most of the heavy metals which would also contribute to the electrical conductivity of the sewage. Nevertheless, the higher electric conduc- 
tivity registered during the March-May sampling period than the June-August period was most likely due to the high inputs of organic and inorganic wastes from the increased runoffs in the wet season than the dry season. However, the results vary depending on the dissolved solids in the discharged water. High EC values indicate the presence of high amount of dissolved inorganic substances in ionized form [34].

\subsubsection{Dissolved Oxygen (DO)}

Dissolved Oxygen is a measure of the degree of pollution by organic matter, the destruction of organic substances; it also tests water body purification [15]. Dissolved oxygen is very important parameter because it determines the dynamics of the biota and is a regulator of metabolic processes in natural water [5]. Dissolved oxygen (DO) also exhibited low within sample variability in both Taso and Kakoba sewage effluents (CV; $20.56 \%$ and $21.97 \%$ respectively) with statistically insignificant $(\mathrm{p}>0.05)$ variation of mean concentration in Taso sewage (68.27 mg/l) compared to levels in Kakoba sewage (63.03 mg/l). However, the mean DO values in both sewage effluents were higher than the EPA and NEMA standard of $5 \mathrm{mg} / \mathrm{l}$. There was no significant variation of DO in Taso sewage effluents $(t=0.627, p=0.565)$ during the March-May and June-August sampling periods. On the other hand, DO was significantly higher during the June-August sampling periods than the March-May periods in Kakoba $(t=6.214, p=0.003)$. The much higher DO in effluents than the EPA and NEMA standard might have resulted from the dissolution of atmospheric oxygen into the effluents during the step-aeration activated sludge treatment process [35]. The higher DO during the June-August sampling periods (dry season) than the March-May periods (wet season) in Kakoba could be associated with increased in wash of organic wastes into the treatment plant during the wet season compared to the dry season. According to [13], the rate of bacterial uptake of oxygen outstrips DO replenishment from the atmosphere and photosynthesis in case large quantities of wastes are discharged into the water body.

\subsubsection{Calcium Carbonate $\left(\mathrm{CaCO}_{3}\right)$}

Calcium Carbonate is a compound which exists in nature as calcite and aragonite in plant ashes, bones, and shells [36] Calcium has an important role in the biological processes of fish and other aquatic organisms [15]. It is necessary for bone formation, blood clotting and other metabolic reactions required for good survival. Calcium and magnesium concentrations expressed as $\mathrm{mg} / \mathrm{C} \mathrm{CaCO}_{3}$ also constitute the total hardness of water [13].

There was very low $(\mathrm{CV}=15.77 \%)$ and very high $(\mathrm{CV}=109.26 \%)$ within sample variability of calcium carbonate $\left(\mathrm{CaCO}_{3}\right)$ concentrations in Taso and Kakoba sewage effluents respectively. Amounts of $\mathrm{CaCO}_{3}$ in Kakoba sewage effluents $(1591.00 \mathrm{mg} / \mathrm{l})$ were also not significantly $(\mathrm{p}>0.05)$ different from levels in Taso sewage $(981.33 \mathrm{mg} / \mathrm{l})$.

However, the mean calcium carbonate hardness of the waters from Kakoba (1591.00 mg/l) and Taso $(981.33 \mathrm{mg} / \mathrm{l})$ sewage effluents were above $350 \mathrm{mg} / \mathrm{l}$, 
EPA threshold for excessively hard water. Therefore, the waters from the sewage plants were excessively hard. Calcium carbonate did not vary significantly during the March-May and June-August sampling periods in Kakoba $(t=2.294, \mathrm{p}=$ 0.084). However, $\mathrm{CaCO}_{3}$ was significantly higher during the June-August sampling period (dry season) than the March-May period (wet season) in sewage effluents in Taso $(t=3.843, p=0.018)$. This may be due to concentration of calcium carbonate in the sewage effluent at higher temperatures during the dry season than during cooler temperatures of the wet season. The significant positive correlation of temperature and $\mathrm{CaCO}_{3}$ obtained by [10] supports the fact that $\mathrm{CaCO}_{3}$ is concentrated at higher temperatures of the dry season compared to the low temperatures of the wet season.

\subsubsection{Magnesium (Mg)}

Magnesium is a dietary mineral element for many organisms. It is also a requirement for plant photosynthesis [21] [37]. Magnesium is found in rivers, rain water and even seawater. Magnesium also exhibited a low within sample variability in Taso sewage effluents $(\mathrm{CV}=21.5 \%)$ and high variability in samples of Kakoba sewage effluent ( $\mathrm{CV}=92.13 \%)$. Levels of $\mathrm{Mg}$ in Kakoba $(243.29 \mathrm{mg} / \mathrm{l})$ and Taso $(246.49 \mathrm{mg} / \mathrm{l})$ sewage effluents were insignificantly $(\mathrm{p}>0.05)$ different from one another. Nevertheless, both the sewage effluents had mean Mg levels much higher than the NEMA maximum permissible limit in waste water of 100 $\mathrm{mg} / \mathrm{l}$. Magnesium recorded no significant difference during the March-May and June-August sampling periods in Kakoba $(\mathrm{t}=2.326, \mathrm{p}=0.081)$ and Taso $(\mathrm{t}=$ $0.733, \mathrm{p}=0.504)$ sewage effluents. The higher mean magnesium levels in both Kakoba and Taso sewage effluents than the NEMA standards is possibly associated with the magnesium compounds added by national water and sewerage corporation of Mbarara municipality as a coagulant to remove organic compounds during treatment of water and this water is carried through the pipes into the sewage treatment plants. According to [38], magnesium compounds due to their high treatment efficiency and low costs are commonly used as coagulant to remove organic compounds during water treatment.

\subsubsection{Iron ( Fe)}

Iron is a metallic element present in many types of rock. It is commonly found in water as an essential element required in small amounts by all living organisms [39]. There was also low variability of iron ( $\mathrm{Fe}$ ) concentrations within samples of Kakoba and Taso sewage effluents (CV; $22.8 \%$ and $38.02 \%$ respectively) (Table 1) with no significant variation in mean Fe levels in Kakoba $(1.13 \mathrm{mg} / \mathrm{l})$ and Taso $(1.13 \mathrm{mg} / \mathrm{l})$ effluents. The mean Fe levels in the effluents were within the EPA standard range $(0.2-2 \mathrm{mg} / \mathrm{l})$ and below the NEMA guideline value (10 $\mathrm{mg} / \mathrm{l})$. The amount of iron was significantly higher during the June-August sampling period than the March-May period in sewage effluents in Kakoba $(\mathrm{t}=$ 5.177, $\mathrm{p}=0.007)$. On the other hand, there was no significant variation of $\mathrm{Fe}$ during the June-August and March-May sampling period in sewage effluents in 
Taso $(t=1.589, \mathrm{p}=0.187)$. Iron displayed low values in the sewage effluents possibly because of the effective removal of iron during the treatment process despite the fact that [10] reported significantly high amounts of Fe downstream of river Rwizi where Mbarara municipality is situated and they attributed this to the urbanized and industrialized area of the municipality. The identified potential sources of iron in the municipality by the same authors included staining from laundries, plumbing and welding, milk and food industries and water treatment plants where cast iron, steel, and galvanized iron pipes are used in water distribution.

However, the sewage treatment processes usually remove heavy metals including Fe [33]. The significantly higher concentration of iron during June-August than March-May period in sewage effluents in Kakoba can also be attributed to concentration of $\mathrm{Fe}$ at slightly higher temperature during the relatively dry season [10].

\subsubsection{Phosphates $\left(\mathrm{PO}_{4}\right)$}

Phosphorus is a vital parameter because it is considered to be the primary driver of eutrophication for aquatic ecosystem, where by the increased nutrient concentrations lead to increased primary productivity [15].

Phosphate also exhibited low variation within samples of Taso $(\mathrm{CV}=18.66 \%)$ and Kakoba $(\mathrm{CV}=28.25 \%)$ sewage effluents and the mean $\mathrm{PO}_{4}$ levels in both sewage effluents i.e. Taso $(32 . \mathrm{mg} / \mathrm{l})$ and Kakoba $(27.11 \mathrm{mg} / \mathrm{l})$ did not vary significantly from each another (Table 1 ). However, the mean phosphate levels in the two sewage effluents were higher than the EPA range $(0.5-0.7 \mathrm{mg} / \mathrm{l})$ and NEMA maximum permissible limit (10 mg/l). Similarly, phosphates also exhibited significantly higher amount during the June-August sampling period than the March -May period in sewage effluents in Kakoba $(t=7.411, p=0.002)$. On the other hand, there was no significant variation of $\mathrm{PO}_{4}$ during the June-August and March -May sampling period in sewage effluents in Taso $(\mathrm{t}=2.288, \mathrm{p}=$ 0.084). The mean phosphate levels in the two sewage effluents were higher than the EPA range and NEMA maximum permissible limit due to ineffective removal of the phosphates by the sewage treatment plants. According to [40], effluent from wastewater treatment plants always has remaining phosphorus. Furthermore, most phosphorus compounds in wastewater are water soluble and precipitation alone can remove just a small fraction. In addition, primary and secondary wastewater treatment processes remove close to $20 \%-30 \%$ of phosphorus with the rest remaining in the wastewater [41].

June-August exhibited significantly higher amount than March-May this was due to increase activities from different detergents from domestic use as seen with [22]. Phosphate is also one of the most important nutrients in waters receiving sewage discharges.

\subsubsection{Nitrates $\left(\mathrm{NO}_{3}\right)$}

Nitrate is a form of nitrogen and vital nutrient for growth, reproduction, and survival for organisms. Nitrate is a very important parameter because it esti- 
mates the organic pollution in a particular area and it represents the highest oxidized form of nitrogen [21]. Nitrate is one of the very common contaminants in the ground and surface waters [29]. Nitrate occurs naturally in source water as a result of decaying plants. Agricultural sources of nitrates include livestock waste matter and chemical fertilizers. Nitrate concentrations exhibited extremely very high variability within samples of both Kakoba (122.47\%) and Taso (174.96\%) sewage effluents with statistically insignificant difference between mean values in Taso $(5.83 \mathrm{mg} / \mathrm{l})$ and Kakoba $(10 \mathrm{mg} / \mathrm{l})$ effluents. The mean $\mathrm{NO}_{3}$ levels were higher than the NWSC maximum permissible limit $(5 \mathrm{mg} / \mathrm{l})$ but below the EPA standard $(50 \mathrm{mg} / \mathrm{l})$. Nitrates were only recorded during the June-August sampling periods but not during the March-May period in both Kakoba and Taso sewage effluents. The higher levels of nitrates in Kakoba and Taso sewage plants than the NWSC maximum permissible limit $(5 \mathrm{mg} / \mathrm{l})$ can also be attributed to inefficiency of the plants in removing nitrates. This is in agreement with [40] who found out that effluents from wastewater treatment plants usually contained nitrogen remaining in the form of nitrates. Nitrates were recorded in dry season partly due to the more aerobic conditions and this favors the rapid conversion of nitrite to nitrate [42]. This is supported by the significantly higher dissolved oxygen in the sewage effluents during the June-August sampling period (dry season) than the March-May period (wet season) in Kakoba $(\mathrm{p}<0.05)$. Therefore, more nitrates are expected during the dry season.

\subsubsection{Ammonium $\left(\mathrm{NH}_{4}\right)$}

Ammonia is a nutrient that contains nitrogen and hydrogen. Its chemical formula is $\mathrm{NH}_{3}$ in the un-ionized state and $\mathrm{NH}_{4}^{+}$in the ionized form [43]. Ammonia is also one of the most important pollutants because it is relatively common but can be toxic, causing lower reproduction and growth, or death. The neutral, un-ionized form $\left(\mathrm{NH}_{3}\right)$ is highly toxic to fish and other aquatic life [44]. There was low within sample variability of ammonium $\left(\mathrm{NH}_{4}\right)$ concentrations in Kakoba sewage effluent $(\mathrm{CV}=5.90 \%)$ and moderate variation in Taso sewage $(\mathrm{CV}=48.99 \%)$. The mean ammonium concentrations in Kakoba sewage effluents $(385.33 \mathrm{mg} / \mathrm{l})$ were significantly $(\mathrm{p}<0.05)$ higher than mean level in Taso sewage effluents $(50.0 \mathrm{mg} / \mathrm{l})$. The mean $\mathrm{NH}_{4}$ levels in both sewage effluents were much higher than the EPA guideline range $(0.2-4 \mathrm{mg} / \mathrm{l})$. This is also in support of the fact that effluents from wastewater treatment plants normally have nitrogen remaining in the form of ammonium even after the treatment. There was no significant variation of ammonium levels during the March-May and June-August sampling periods in both Kakoba $(\mathrm{t}=2.000, \mathrm{p}=0.116)$ and Taso $(\mathrm{t}=1.000, \mathrm{p}=$ 0.374) sewage effluents.

\subsubsection{Chloride (Cl)}

Chlorides are essential elements of life and it is present in both fresh and salt water [45]. Small amounts of chlorides are required for normal cell functions in plant and animal life. Elevated chloride levels have been studied by scientists as 
one indicator of pollution in a body of water. High chloride levels in fresh water bodies can harm aquatic organisms whereby they can interfere with osmoregulation, a biological process by which organisms maintain the proper amount of concentrations of salt and other solutes in the bodily fluids [45]. Chloride was only recorded in Kakoba sewage effluents (mean $=833.33 \mathrm{mg} / \mathrm{l}$ ) but not in Taso sewage (Table 1$)$ and it exhibited moderate variability within samples $(\mathrm{CV}=$ 48.99\%). The mean $\mathrm{Cl}$ levels in Kakoba sewage effluents were higher than EPA $(250 \mathrm{mg} / \mathrm{l})$, NWSC and NEMA (500 mg/l) standards. Concentrations of $\mathrm{Cl}$ in Kakoba sewage effluents did not vary significantly during the March-May and June-August sampling periods $(\mathrm{t}=1.000, \mathrm{p}=0.374)$. The complete absence of chloride in Taso may possibly be attributed to some technical challenges during measurement chloride but not due to complete absence of chloride in sewage effluents in Taso. Hence more studies are required to confirm the values of chloride in sewage effluents in Taso.

The higher mean $\mathrm{Cl}$ levels in Kakoba sewage effluents than the standard values are most likely attributed to the addition of reactive chemicals like chlorine as a disinfectant of water of pathogenic microorganisms during water treatment by national water and sewerage corporation [46]. This piped water also ends up into the sewage treatment plant.

\section{Conclusion}

Different parameters of wastewater were analyzed to judge the physico-chemical characteristics of wastewater which was being discharged from two municipal sewage treatment plants (Taso, Kakoba) in Mbarara Municipality. Results obtained varied from site to site due to the nature of wastes generated from the various activities carried out around the treatment plants. However, the mean values of most of the physico-chemical parameters tested (colour, alkalinity, dissolved oxygen, magnesium, $\mathrm{pH}$, phosphate, nitrate ammonium, and chloride) in both Taso and Kakoba treatment plants were higher than the recommended EPA, NWSC and NEMA standards for waste water. Therefore the study recommends effective treatment of waste effluents from Kakoba and Taso sewage treatment plants during recycling in order to avoid pollution of river Rwizi.

\section{Acknowledgements}

The authors would like to thank African Development Bank Hest, Mbarara University of Science and Technology, for providing the financial support. Biology Department, Faculty of Science, National water and Sewerage co-operation, for allowing me use their laboratories sample analyses. We also thank for Agaba Edson and Araka Nickson my research assistants, Mr. Rapheal Wangalwa, Mr. Tumusiime Julius, for their time whenever approached for assistance, friends and all well-wishers.

\section{Conflicts of Interest}

The authors declare no conflicts of interest regarding the publication of this paper. 


\section{References}

[1] Egor, M., Mbabazi, J. and Ntale, M (2014) Heavy Metal and Nutrient Loading of River Rwizi By Effluents from Mbarara Municipality, Western Uganda. International Journal of Chemistry and Materials Research, 2, 36-47.

[2] Fagan, G.H., Linnane, S., McGuigan, K,G. and Rugumayo, A.I. (2015) Water Is Life, Progress to Secure Safe Water Provision in Rural Uganda Rugby. Practical Action Publishing, UK. https://doi.org/10.3362/9781780448893

[3] International Water Stewardship Programme (IWaSP) (2017) Act Phase Success Story-River Rwizi, Uganda. Improved Community Livelihoods and Sustainable Water Management in the River Rwizi Catchment. https://ceowatermandate.org/wraf/wp-content/uploads/sites/22/2017/10/IWaSP_A CT_Uganda-River-Rwizi_17.05.2017.pdf

[4] Lukubye, B. and Andama, M. (2017) Bacterial Analysis of Selected Drinking Water Sources in Mbarara Municipality, Uganda. Journal of Water Resource and Protection, 9, 999-1013. https://doi.org/10.4236/jwarp.2017.98066

[5] Busulwa, H.S. and Bailey, R.G. (2004) Aspects of the Physico-Chemical Environment of the Rwenzori Rivers, Uganda. African Journal of Ecology, 42, 87-92. https://doi.org/10.1111/j.1365-2028.2004.00467.x

[6] Ravishankar, C., Nautiyal, S. and Seshaiah, M. (2018) Social Acceptance for Reclaimed Water Use: A Case Study in Bengaluru. Recycling, 3, 4. https://doi.org/10.3390/recycling3010004

[7] Ojok, W., Wasswa, J. and Ntambi, E. (2017) Assessment of Seasonal Variation in Water Quality in River Rwizi Using Multivariate Statistical Techniques, Mbarara Municipality, Uganda. Journal of Water Resource and Protection, 9, 83-97. https://doi.org/10.4236/jwarp.2017.91007

[8] WHO (n.d.) Water Sampling and Analysis. https://www.who.int/water_sanitation_health/dwq/2edvol3d.pdf

[9] American Public Health Association (2005) Standard Methods for the Examination of Water and Wastewater. 21st Edition, American Public Health Association, American Water Works Association and Water Environment Federation, Washington DC.

[10] Twebembeire, J., Bazira, J., Kagoro, G., Yatuha, J., Andama, M. and Bunny, J.L. (2018) The Physico-Chemical Quality of Streams and Channels Draining into River Rwizi, South Western Uganda. Journal of Water Resource and Protection, 10, 817-845. https://doi.org/10.4236/jwarp.2018.109047

[11] Dimowo, B.O. (2013) Assessment of Some Physico-Chemical Parameters of River Ogun (Abeokuta, Ogun State, Southwestern Nigeria) in Comparison with National and International Standards. International Journal of Aquaculture, 3, 79-84. https://doi.org/10.5376/ija.2013.03.0015

[12] NEMA (1999) National Environment (Standards for Discharge of Effluent or Waste Water into Water or on Land) Regulations. National Environment Management Authority (NEMA), Government of the Republic of Uganda, Kampala. http://nema.go.ug/sites/all/themes/nema/docs/effluent_discharge_regulations.pdf

[13] EPA (2001) Parameters of Water Quality: Interpretation and Standards. Environmental Protection Agency, Wexford. https://www.epa.ie/pubs/advice/water/quality/Water_Quality.pdf

[14] Messrouk, H., Hadj M.M., Touil, Y. and Amrane, A. (2014) Physico-Chemical Characterization of Industrial Effluents from the Town of Ouargla (South East Algeria). Energy Procedia, 50, 255-262. https://doi.org/10.1016/j.egypro.2014.06.031 
[15] Benit, N. and Roslin, A.S. (2015) Physicochemical Properties of Wastewater Collected from Different Sewage Sources. International Journal of Innovative Science, Engineering \& Technology, 2, 6.

[16] National Water and Sewerage Corporation (NWSC) (2015) National Standards for Wastewater. National Water and Sewerage Corporation Regional Laboratory, Mbarara. ID NO: NWSC-MBR/ENG/RD/16.

[17] Morrison, G., Fatoki, O.S., Persson, L. and Ekberg, A. (2001). Assessment of the Impact of Point Source Pollution from the Keiskammahoek Sewage Treatment Plant on the Keiskamma River-pH, Electrical Conductivity, Oxygen-Demanding Substance (COD) and Nutrients. Water $S A, 27,475-480$. https://doi.org/10.4314/wsa.v27i4.4960

[18] Tabacchi, E., Correll, D.L., Hauer, R., Planty-Tabacchi, A. and Wissmar, C.R. (1998) Development, Maintenance and Role of Riparian Vegetation in the River Landscape. Freshwater Biology, 40, 497-516. https://doi.org/10.1046/j.1365-2427.1998.00381.x

[19] Zamxaka, M., Pironcheva, G. and Muyima, N.Y.O. (2004) Microbiological and Physico-Chemical Assessment of the Quality of Domestic Water Sources in Selected Rural Communities of the Eastern Cape Province, South Africa. Water SA, 30, 333-340.

[20] Walakira, P. and Okot-Okumu, J. (2011) Impact of Industrial Effluents on Water Quality of Streams in Nakawa-Ntinda, Uganda. Journal of Applied Sciences and Environmental Management, 15, 289-296. https://doi.org/10.4314/jasem.v15i2.68512

[21] Asghar, M.Z., Arshad, A., Hong, L., Riaz, M. and Arfan, M. (2018) Comparative Assessment of Physico-Chemical Parameters of Waste Water Effluents from Different Industries in Lahore, Pakistan. Proceedings of the International Academy of Ecology and Environmental Sciences, 8, 99-112.

[22] Venkatesharaju, K., Ravikumar, P., Somashekar, R.K. and Prakash, K.L. (2010) Physico-Chemical and Bacteriological Investigation on the River Cauvery of Kollegal Stretch in Karnataka. Kathmandu University Journal of Science, Engineering and Technology, 6, 50-59. https://doi.org/10.3126/kuset.v6i1.3310

[23] Walakira, P. (2011) Impact of Industrial Effluents on Water Quality of Receiving Streams in Nakawa-Ntinda, Uganda. M.Sc. Thesis (Unpublished), Makerere University, Kampala, 58.

https://news.mak.ac.ug/documents/Makfiles/theses/Walakira_Paul.pdf

[24] Lewis, M.J. and Bamforth, C.W. (2006) pH. In: Essays in Brewing Science, Springer, Boston, MA. https://doi.org/10.1007/0-387-33011-9_2

[25] Adefemi, S.O. and Awokunmi, E.E. (2010) Determination of Physico-Chemical Parameters and Heavy Metals in Water Samples from Itaogbolu Area of Ondo-State, Nigeria. African Journal of Environmental Science and Technology, 4, 145-148. https://doi.org/10.5897/AJEST09.133

[26] Mustapha, M.K. and Omotoso, J.S. (2008) An Assessment of the Physico-Chemical Properties of Moro Lake. African Journal of Applied Zoology and Environmental Biology, 7, 73-77. https://doi.org/10.4314/ajazeb.v7i1.41151

[27] Ajithkumar, T.T., Thangaradjou, T. and Kannan, L. (2006) Physico-Chemical and Biological Properties of the Muthupettai Mangrove in Tamil Nadu. Journal of Marine Biological Association of India, 48, 131-138.

[28] Rahmanian, N., Ali, B.S.H., Homayoonfard, M., Ali, N.J., Rehan, M. and Sadef, Y. (2015) Analysis of Physiochemical Parameters to Evaluate the Drinking Water 
Quality in the State of Perak, Malaysia. Journal of Chemistry, 2015, Article ID: 716125. https://doi.org/10.1155/2015/716125

[29] Lokhande, R.S., Singare, P.U. and Pimple, D.S. (2011) Study on Physico-Chemical Parameters of Waste Water Effluents from Taloja Industrial Area of Mumbai, India. International Journal of Ecosystem, 1, 1-9. https://doi.org/10.5923/j.ije.20110101.01

[30] Tjadraatmadja, G. and Diaper, C. (2006) Sources of Critical Contaminants in Domestic Wastewater-A Literature Review. CSIRO: Water for a Healthy Country National Research Flagship.

http://www.clw.csiro.au/publications/waterforahealthycountry/2006/wfhc-criticalco ntaminants-sources-domesticwastewater.pdf

[31] Igbinosa, E.O. and Okoh, A.I. (2009) Impact of Discharge Wastewater Effluents on the Physico-Chemical Qualities of a Receiving Watershed in a Typical Rural Community. International Journal of Environmental Science \& Technology, 6, 175-182. https://doi.org/10.1007/BF03327619

[32] Gorchev, H.G. and Ozolins, G. (2011) WHO Guidelines for Drinking-Water Quality. WHO Chronicle, 38, 104-108.

[33] Xiang, X., Chan, L.C. and Wong, J.W.C. (2000) Removal of Heavy Metals from Anaerobically Digested Sewage Sludge by Isolated Indigenous Iron-Oxidizing Bacteria. Chemosphere, 41, 283-287. https://doi.org/10.1016/S0045-6535(99)00422-1

[34] Lukubye, B. and Andama, M. (2017) Physico-Chemical Quality of Selected Drinking Water Sources in Mbarara Municipality, Uganda. Journal of Water Resource and Protection, 9, 707-722. https://doi.org/10.4236/jwarp.2017.97047

[35] Du, X., Wang, J., Jegatheesan, V. and Shi, G (2018) Dissolved Oxygen Control in Activated Sludge Process Using a Neural Network-Based Adaptive PID Algorithm. Applied Sciences, 8, 261. https://doi.org/10.3390/app8020261

[36] Lu, S., Wang, J. and Pei, L. (2016) Study on the Effects of Irrigation with Reclaimed Water on the Content and Distribution of Heavy Metals in Soil. International Journal of Environmental Research and Public Health, 13, 298.

https://doi.org/10.3390/ijerph13030298

[37] Igbinosa, E.O. and Okoh, A.I. (2009) Impact of Discharge Wastewater Effluents on the Physico-Chemical Qualities of a Receiving Watershed in a Typical Rural Community. International Journal of Environmental Science \& Technology, 6, 175-182. https://doi.org/10.1007/BF03327619

[38] Liang, M. (2009) New Possibilities of Magnesium Utilization in Wastewater Treatment and Nutrients Recovery. Master's Thesis, Department of Land and Water Resources Engineering, Royal Institute of Technology, Stockholm. https://www.diva-portal.org/smash/get/diva2:302586/FULLTEXT01.pdf

[39] Valko, M., Morris, H. and Cronin, M.T.D. (2005) Metals, Toxicity and Oxidative Stress. Current Medicinal Chemistry, 12, 1161-1208. https://doi.org/10.2174/0929867053764635

[40] Yamashita, T. and Yamamoto-Ikemoto, R. (2014) Nitrogen and Phosphorus Removal from Wastewater Treatment Plant Effluent via Bacterial Sulfate Reduction in an Anoxic Bioreactor Packed with Wood and Iron. International Journal of Environmental Research and Public Health, 11, 9835-9853. https://doi.org/10.3390/ijerph110909835

[41] Ruzhitskaya, O. and Gogina, E. (2017) Methods for Removing of Phosphates from Wastewater. MATEC Web of Conferences 106, 07006 (2017). SPbWOSCE-2016. https://doi.org/10.1051/matecconf/201710607006

[42] Nwankwoala, H.O., Pabon, D. and Amadi, P.A. (2009) Seasonal Distribution of Ni- 
trate and Nitrite Levels in Eleme Abattoir Environment, Rivers State, Nigeria. Journal of Applied Sciences and Environmental Management, 13, 35-38

[43] Ugwu, E.I., Uzoma, N.E. and Ikechukwu, E.L. (2016) Study on Physiochemical Parameters of Water Samples from Onuimo River Imo State, Nigeria. South Asian Journal of Engineering and Technology, 2, 1-8.

[44] Hargreaves, J.A. and Tucker, C.S. (2004) Managing Ammonia in Fish Ponds (Vol. 4603). Southern Regional Aquaculture Center, Stoneville.

[45] Hunt, M., Herron, E. and Green, L. (2012) Chlorides in Fresh Water. College of the Environment and Life Sciences, The University of Rhode Island, Kingston http://cels.uri.edu/docslink/ww/water-quality-factsheets/Chlorides.pdf

[46] WHO (2011) Guidelines for Drinking-Water Quality. 4th Edition, World Health Organization Press, Geneva.

http://apps.who.int/iris/bitstream/10665/44584/1/9789241548151_eng.pdf 